\title{
Imperfect Markets, Imperfect Competition and Basic Model
}

\section{Brunela Trebicka, MSc}

Universiteti "Aleksandër Moisiu"

Durrës, Albania

brunelat@hotmail.com

Doi:10.5901/mjss.2014.v5n16p706

\begin{abstract}
This paper has focused on static environments or on single-agent dynamic decision problems. Many economic policy debates, however, turn on quantities that are inherently linked to dynamic competition, such as entry and exit costs, the returns to advertising or research and development, the adjustment costs of investment, or the speed of firm and consumer training. Estimating these dynamic parameters has been seen as a major challenge, both conceptually and computationally. In the perfectly competitive markets, the firms do not perceive they have any market power. Imperfect competition is a market situation where individual firms have a measure of control over the price of the commodity in an industry. In these conditions we can identify a firm or e few firms that can affect the market price of their outputs. These firms can be classified as imperfect competitors. Normally, imperfect competition arises when an industry's output is supplied only by one, or a relatively small number of firms. Profit-maximizing firms in an imperfectly competitive market will charge a mark-up of price over marginal costs. The size of the mark-up depends on the price elasticity of demand and on the degree of competition, such that an increase in the number of firms reduces the mark-up. In a general equilibrium setting, imperfect competition leads to a suboptimal outcome (a deviation between MRS and MRT). Since international trade increases market competition, as foreign firms start to compete on the domestic market and vice versa, international trade improves economic efficiency (by diminishing the deviation between MRS and MRT), the so-called pro-competitive gains from trade. A basic model for imperfect markets is given for two firms, firm 1 and firm 2. We develop a model of advertising in a differentiated duopoly in which firms first decide how much to invest in cooperative or predatory advertising and then engage in product market competition (Cournot or Bertrand).
\end{abstract}

Keywords: Imperfect Competition, Imperfect Market, Monopoly, Oligopoly, Cournot, Cooperative Advertising.

\section{Introduction}

Strategic trade policy has become an important part of the international trade policy analysis since the paper written by (Brander, J. and B. Spencer, 1984) was published. Since then, the policy implication has been controversial, mainly because the ex ante trade policy recommendation is very sensitive to the ex post market conducts. The late studies has shown that if a firm engages in strategic investment competition as Research and development or increase in capacity, prior to archive market competition, then the industrial policy will be more tough than trade policy. (Neary \& Leahy, 2000) developed a general framework to analyze optimal intervention towards dynamic oligopoly, emphasizing the implications of different kinds of government commitment. They said that when companies make strategic investment before producing market competition, the first-best policy combination should be designed for both profit-shifting and correcting the domestic firm's strategic behavior to influence the rival's decision and the domestic government's decision (if possible), which is socially wasteful. They also argue that a general model may not be the right one to provide guide on policy making, and that it might be better to conduct case studies of particular policy combinations. Advertising is a good area for such a case study, since its policy implications in the context of strategic trade policy have not been much explored.

In this paper, we first talk about imperfect market; monopoly, oligopoly and then we talk about monopolistic competition. In the part two we talk about Imperfect competition. In part three we construct a model of advertising in a differentiated duopoly. This model is represented as a two stage game. In the first stage, firms decide how much to invest in cooperative advertising, and in the second stage, the firm engage in product market competition.

We then analyze policy setting in the context of a Brander-Spencer third-country model of strategic trade, beginning with the case where governments can set trade and industrial policies, and then considering the cases where they can set only industrial policy or only

trade policy. 


\section{Imperfect Markets}

\subsection{Monopoly}

Monopoly is a market situation where a single seller exists and has complete control over an industry. Since it is the only firm active in the market, its actions have a large impact on the market. In monopolistic market, a firm is independence; means that firm in this market are hardly affected with their competitors act or decision, or vice versa (Sloman and Norris, 2002). Not found in the list of references Firms in the monopolistic market are offering their products through different things from their competitors; appearance, levels, technology, quality, price, etc. These differentiations of product are also known as Product differentiation (Parkin, 2000) Not found in the list of references. The monopolist's profit maximization problem is e more sophisticated than the problem facing a perfectly competitive firm which treats the output price as a parameter. A monopolist gathers information not only about its own production processes and cost structure, but also about the market for its product and the responsiveness of this market to changes in the price charged by the monopolist. Fig 1 illustrates the monopolist's problem. The market demand curve is given by the downward-sloping solid line. It is assumed to be linear, which implies that the marginal revenue (MR) curve is also linear, with the same intercept and a slope twice as steep (Franz, 2003). The marginal revenue curve is steeper than the demand curve because the firm has to lower its price if it wants to sell more goods, which also lowers the revenue on the initial output.

Figure 1: Optimal outputs for a monopolist

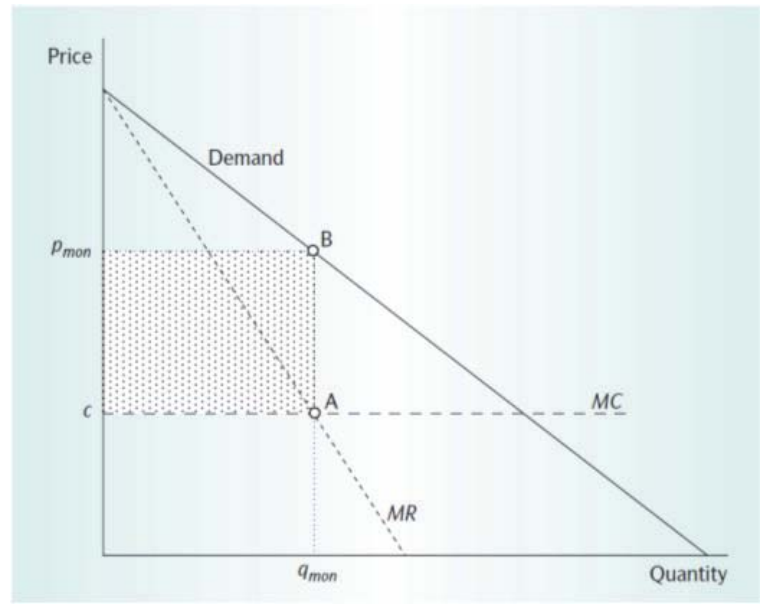

Source: Marrewijk, (Chapter 9, 2002)

The most important thing to note about Fig 1 is that the price charged by the monopolist is higher than the marginal cost of production. In determining the optimal price for its products, the monopolist thus charges a mark-up over the marginal cost of production. This mark-up depends on the price elasticity of demand as follows:

$$
p\left(1-\frac{q_{A}}{q} \frac{1}{\varepsilon(q)}\right)=c\left(q_{A}\right)
$$

\subsection{Oligopoly}

Oligopoly is a market structure with few sellers; Market power can, of course arise if there are only a few firms, rather than one, active in a market. If there are just two firms, the market is called a duopoly (Cournot model 1838). Firms operating in an oligopolistic market situation may either collude or act independently. As illustrated in Fig 2 given there are two firms operating in the market and that the B firm produces $q B 0$ units of goods, the A firm's optimal output choice must determine the optimal output combination on the dashed horizontal line generated by point $q B 0$. Since the $A$ firm maximizes profits, this dashed line must be tangent to one of its isoprofit curves, some of which are also drawn in Fig 2. The optimal production level for the A firm, given that the $B$ firm produces $q B 0$, is therefore equal to $q A 0$. Second, if the $B$ 
firm increases its output level from $q B 0$ to $q B 1$, this reduces the price level in the market and the $A$ firm's profitability. Consequently, the A firm's optimal response is then a reduction in output, from $q A 0$ to $q A 1$. Third, similar reactions by the A firm to changes in the output level of the B firm are given by the dots in Fig 2. Connecting all such dots gives the reaction curve of the $A$ firm. Fourth, note that if the output level of the $B$ firm is equal to zero, the $A$ firm's problem reduces to that of a monopolist. Clearly this leads to the maximum attainable profits for the A firm, at point qmon in Fig 2. The isoprofit curves of the A firm in Fig 2 increase as they approach qmon. As already remarked above, the B firm faces a similar problem as the A firm.

Figure 2: Derivation of firm A reaction curve

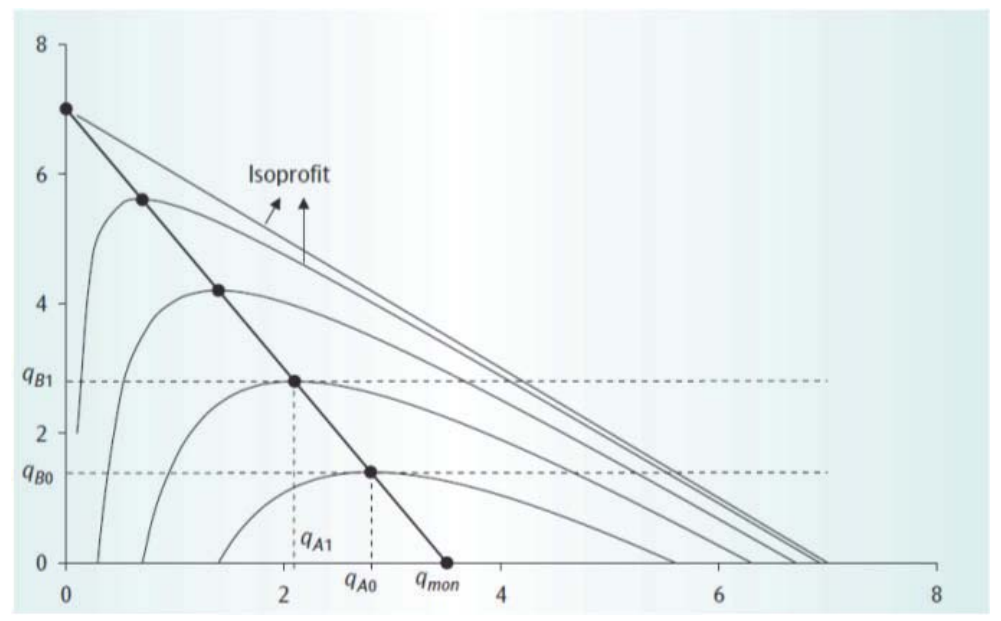

Source: Marrewijk, (Chapter 9, 2002)

Given the linear market demand $p=a-b q$ and the fact that total output is the sum of the A firm's and B firm's output, it follows that the A firm's profits $\pi_{A}$ depend on the B firm's output level as follows:

$\pi_{A=(p-c)} q_{A=\left[(a-c)-b\left(q_{A+q_{B}}\right)\right]} q_{A}$

where $\mathrm{c}$ is the marginal cost of production.

While equation here below indicates that the marginal-revenue-equals-marginal-cost rule which the $\mathrm{A}$ firm applies leads to a mark-up of price over marginal cost depending on:

- the price elasticity of demand $\varepsilon(q)$ prevailing in the market; and

- the A firm's market share $q_{A} / q$.

$p\left(1-\frac{q_{A}}{q} \frac{1}{\varepsilon(q)}\right)=c\left(q_{A}\right)$

More specifically, the higher the price elasticity of demand, the lower the mark-up, and the lower the A firm's market share the lower the mark-up. In the limit, as the number of firms in the Cournot model becomes arbitrarily large and the A firm's market share becomes arbitrarily small, the mark-up disappears and the price becomes equal to the marginal cost of production, as in the perfectly competitive model. One of the main attractions of the Cournot model is therefore that it reduces to the monopoly model if there is only one firm, than to the monopolistic competition and to the perfectly competitive model if there are arbitrarily many firms.

\subsection{Monopolistic competition}

Monopolistic competition occurs when there are many sellers producing differentiated products (Ramasubramanian, 2004). Monopolistic competition is a type of imperfect competition such that many producers sell products that are differentiated from one another as goods but not perfect substitutes (such as from branding, quality, or location). In monopolistic competition, a firm takes the prices charged by its rivals as given and ignores the impact of its own prices on the prices of other firms (Krugman and Obstfeld, 2009). Firms have slight control over the price of the commodity and 
they advertise. The model for this case is not developed here in this essay and will be subject to another essay.

\section{Imperfect Competition}

Many applied economic studies deal with the estimation of structural models of decision-making and equilibrium. Most of this work is focused on static environment or single-agent dynamic decision problem. Many of economic policy debates, turn on quantities that are inherently linked to dynamic competition, such as entry and exit costs, the returns to advertising or research and development, the adjustment cost of investment, or the speed of firm and consumer training (Noe and Parker, 2005). Estimating these dynamic parameters has been seen as a major challenge, both conceptually and computationally.

In the perfectly competitive markets, the firms fill they don't have any market power, they do not think they can influence the price at which the market clears. All firms individually, therefore, take the market-clearing price as given in their profit maximization problem. Each firm determines how much it will produce at any given price level. The actions of all firms together determine the market supply. This is confronted with the demand of consumers to determine the price at which the market actually clears. Collectively, the firms therefore do influence the market-clearing price. If there are many firms, the impact of any individual firm on the market-clearing price is negligible; hence the assumption that each firm takes this price as given. In many cases the assumption of perfect competition is a reasonable approximation.

If a firm does not take the price level on the market as given, but strategically interacts with other firms and the market to maximize its profits, we are no longer in the realm of 'perfect competition'. Instead, we say such a market is characterized by 'imperfect competition', a poorly chosen term indeed, certainly in those cases in which it gives a better description of the market (Farrell and Klemperer, 2007). Since there is an unlimited number of ways in which firms can deviate from the market's perfect competition, there are many different 'imperfect' models, leading to many different outcomes and policy prescriptions. Thus, imperfect competition is hard to model in a general equilibrium setting, certainly in conjunction with production under increasing returns to (Epifani and Gancia, 2006).

Imperfect competition is a market situation where individual firms have a measure of control over the price of the commodity in an industry (O'Sullivan and Sheffrin, 2003). In these conditions we can identify a firm or e few firms that can affect the market price of their outputs. These firms can be classified as imperfect competitors. Normally, imperfect competition arises when an industry's output is supplied only by one, or a small number of firms(Lee, 2002).

While, an imperfect market is a situation where individual firms have some measure of control or discretion over the price of the commodity in an industry. In such markets the imperfect competition does not necessarily mean that a firm can arbitrarily put any price on its commodity (Chen, Narasimhan, and Zhang, 2001). This due to the fact that an imperfect competitor does not have absolute power over price. Aside from discretion over price, imperfect competitors may or may not have product differentiation or variation.

\subsection{Demand curve faced by firm}

The firm under an imperfect market faces the market demand curve or part of it. In either case, the firm faces a downward sloping demand curve (Gowrisankaran and Rysman, 2009). This implies that if the firm wants to sell more, it should lower the price; if it wishes a higher price, it should restrict the output.

In contrast, a perfectly competitive firm faces a horizontal demand curve since the firm has no control over price.

\subsection{Sources of market imperfection}

Imperfect competition often arises when an industry's output is supplied by one or a small number of firms (Chang and Lai, 2012). This may be traced to the existence of barriers to entry or exit and the existence of significant differences or advantages in cost conditions. The barriers to entry or exit can be as follow:

- Barriers to entry - natural or artificial constraints that prevent other firms from entering the industry

- Legal restrictions like patents and exclusive franchises;

- Existence of advantages in cost conditions - demand for commodity may be too small, firm's production function may exhibit increasing returns to scale (LAC curve shows economies of scale over all profitable output levels).

- Industrial citizenship established by the principal competitor

and 
- Barriers to exit - administrative or industry specifics related

- Closure cost barriers - high fixed costs

- Legal restrictions related to innovation monopoly and to technologic secrets

\section{The Basic Model}

The basic model is given as a two-stage game. In the first stage are presented two firms, firm

1 and firm 2. Firms produce a differentiated product respectively, decide simultaneously how much to invest in cooperative advertising, or predatory advertising, or both.

In the second stage they engage in product market competition.

Consumers assume that the representative consumer's preferences are given by the following utility function:

$\mathrm{U}\left(\mathrm{x}_{1}, \mathrm{x}_{2}, \mathrm{~m}\right)=\mathrm{u}\left(\mathrm{x}_{1}, \mathrm{x}_{2}\right)+\mathrm{m}$

where $x_{1}$ and $x_{2}$ are the outputs of the two firms respectively and $m$ is a countable good.

Also:

$u\left(x_{1}, x_{2}\right)=a_{1} x_{1}+a_{2} x_{2}-\frac{1}{2}\left\{b\left(x_{1}\right)^{2}+2 x_{1} x_{2}+b\left(x_{2}\right)^{2}\right\}$

where:

$a_{1}=a\left[1+\mu\left(m_{i}+m_{j}\right)+v\left(n_{i}-n_{j}\right)\right]$

$a>0 ; b>1 ; \mu>0 ; v>0 ; i=1,2 ; j=1,2 ; i \neq j$

$a_{1}$ measures the market scale for firm i.

$a$ is the base of market scale: when firms do not make investment on advertisement $a_{i}=a$.

b represents the sensitivity of demand to a firm's own product. For simplicity, we assume that the sensitivity of demand to the rival firm's product is equal to 1 .

$m_{i}$ and $n_{i}$ are the respective cooperative and predatory advertising levels of firm i.

$\mu$ and $v$ evaluate the effectiveness of the two types of advertising respectively.

Denote by pi the price for each firm's product. Then the indirect demand system is given by:

$p_{i}=a_{i}-b x_{i}-x_{i}$

The corresponding direct demand system is given by:

$x_{i}=\alpha_{i}-\beta p_{i}+\gamma p_{j}$

This formulation implies that one unit of a firm's cooperative advertising investment will increase its own market scale and the rival's market scale by a $\mu$ units when firms play Cournot and by $\alpha \mu=\left(\frac{\alpha}{b+1}\right) \mu$ units when firms play Bertrand; one unit of a firm's predatory advertising investment will make its own market scale increase and the rival's market scale decrease by av units when firms play Cournot and make its own market scale increase and the rival's market scale decrease by $\mathrm{a}\left(\frac{b+1}{b-1}\right) v=\left(\frac{\alpha}{b-1}\right) v$ units when firms play Bertrand.

To simplify notation, without loss of generality, we normalize $v=1$, and henceforth interpret $\mu$ as a measure of the relative effectiveness of cooperative advertising.

Firms:

Firm i maximizes profit $\Pi_{\mathrm{i}}$

We assume that firms have the same production technology, and their cost function is as follow:

technologies, with cost function: $\mathrm{C}_{\mathrm{i}}\left(\mathrm{x}_{\mathrm{i}}\right)=\mathrm{C} \mathrm{x}_{\mathrm{i}}, \mathrm{i}=1,2$, where, for the usual reason, $\mathrm{a}>\mathrm{c}$.

The investment cost function of each firm is given by $C_{i}\left(m_{i}^{\prime} n_{i}\right)=\frac{1}{2} k\left(m_{i}+n_{i}\right)^{2}$, i.e., we suppose that there exists a joint investment diseconomy for each firm ${ }^{1}$, where

$\frac{\partial c i}{\partial m i}=\frac{\partial c i}{\partial n i}=\mathrm{k}\left(\mathrm{mi}_{\mathrm{i}}+\mathrm{n}_{\mathrm{i}}\right)$

We make the following assumption on $\mathrm{k}$.

Assumption $\underline{\mathrm{k}}<\mathrm{k}<{ }^{-} \mathrm{k}$, where

$\mathrm{k}=2 \max \left\{\mathrm{k}_{1}, \mathrm{k}_{2}, \mathrm{k}_{3}, \mathrm{k}_{4}\right\}$

The first inequality in Assumption sets the greatest lower bound on $\mathrm{k}$ and ensures that in the investment stage of

\footnotetext{
1 It might be argued that such a formulation cannot capture the potential increasing-return-to-scale effects of advertising. However, the problem might not be so serious as it seems to be. If advertising investment incurs a fixed cost, then there will be an increasing-return-toscale range for investment. Clearly a firm will invest in advertising only within this range. If we make an appropriate additional assumption on the fixed cost, our analysis will still hold. Of course, fixed costs are one of the important factors determining market structure. However, it is not the focus of this paper and we assume that the market structure is given.
} 
the game:

1. the profit function of each firm will be a concave function in its own choice,

2. the own effect of any type of advertising will be greater than the corresponding cross effect.

The second inequality sets an upper bound on $\mathrm{k}$ to ensure that firms' advertising investments are not so low as to be negligible.

We now solve for the Subgame Perfect Nash Equilibrium (SPNE) of the basic model.

\section{Conclusions}

Profit-maximizing firms in an imperfectly competitive market will charge a mark-up of price over marginal costs (Rotemberg and Woodford, 1999). The size of the mark-up depends on the price elasticity of demand and on the degree of competition, such that an increase in the number of firms reduces the mark-up. In a general equilibrium setting, imperfect competition leads to a sub-optimal outcome (a deviation between MRS and MRT). Since international trade increases market competition, as foreign firms start to compete on the domestic market and vice versa, international trade improves economic efficiency (by diminishing the deviation between MRS and MRT), the so-called pro-competitive gains from trade.

The main results of this paper are: first, firms will invest only in one type of advertising, which is determined by the relative effectiveness of the two types of advertising and the degree of product differentiation. Second, when governments use both trade and industrial policies, these policies are substitutes. Third, new evidence is found to support trade policy. When governments can use only trade policy, for a range of parameters, which can be wide, trade policy in the form of a trade subsidy is similarly robust, i.e., governments always use that irrespective of the type of advertising or form of market competition. Fourth, further evidence is found to support industrial policy. When governments can use only industrial policy, it is robust, i.e., governments will always use an advertising subsidy irrespective of the type of advertising and form of market competition.

\section{References}

Brander, J. and B. Spencer. (1984). Tariff Protection and Imperfect Competition. Imperfect Competition and International Trade,(The MIT Press, Cambridge,(1992)), 107-119.

Chang, C. wei, \& Lai, C. chong. (2012). Markups and the number of firms in a simple model of imperfect competition. Economics Letters, 116, 277-280. doi:10.1016/j.econlet.2012.04.005

Chen, Y., Narasimhan, C., \& Zhang, Z. J. (2001). Individual Marketing with Imperfect Targetability. Marketing Science. doi:10.1287/mksc.20.1.23.10201

Epifani, P., \& Gancia, G. (2006). Increasing Returns, Imperfect Competition, and Factor Prices. Review of Economics and Statistics. doi:10.1162/rest.88.4.583

Farrell, J., \& Klemperer, P. (2007). Chapter 31 Coordination and Lock-In: Competition with Switching Costs and Network Effects. Handbook of Industrial Organization. doi:10.1016/S1573-448X(06)03031-7

Franz, M. R. (2003). The electrical restitution curve revisited: steep or flat slope--which is better? Journal of Cardiovascular Electrophysiology, 14, S140-S147. doi:10.1046/j.1540.8167.90303.x

Gowrisankaran, G., \& Rysman, M. (2009). Dynamics of Consumer Demand for New Durable Goods. NBER Working Paper, 1-25. doi:10.1086/669540

Krugman, P. R., \& Obstfeld, M. (2009). International economics: theory and policy. Policy (Vol. New York,, p. 706). Retrieved from http://scholar.google.com/scholar?hl=en\&btnG=Search\&q=intitle:International+Economics+Theory+and+policy\#0

Lee, S.-W. (2002). An Economic Analysis of the Movie Industry in Japan. Journal of Media Economics. doi:10.1207/S15327736ME1502_4

Neary, J. P., \& Leahy, D. (2000). Strategic trade and industrial policy towards dynamic oligopolies. Economic Journal, 110, 484-508. doi:10.1111/1468-0297.00534

Noe, T., \& Parker, G. (2005). Winner Take All: Competition, Strategy, and the Structure of Returns in the Internet Economy. Journal of Economics \& Management Strategy, 14, 141-164. doi:doi:10.1111/j.1430-9134.2005.00037.x

O'Sullivan, A., \& Sheffrin, S. M. (2003). Economics: Principles in action. Upper Saddle River New Jersey 07458 (p. 474). Retrieved from http://www.pearsonschool.com/index.cfm?locator=PSZ3R9\&PMDbSiteld=2781\&PMDbSolutionld=6724\&PMDbCategoryld=\&PM DbProgramld=12881\&level=4

Ramasubramanian, S. (2004). Introduction to game theory. Resonance. doi:10.1007/BF02834992

Rotemberg, J. J., \& Woodford, M. (1999). Chapter 16 The cyclical behavior of prices and costs. Handbook of Macroeconomics. doi:10.1016/S1574-0048(99)10024-7 